Миланка Ј. Бабић

Универзитет у Источном Сарајеву

Филозофски факултет Пале

Катедра за србистику

https://doi.org/10.18485/ai_zsjoski.2019.2.ch4

821.163.41-31.09 Селимовић М.

811.163.41'373.72

\title{
ГРАМАТИКА И СЕМАНТИКА САМОЋЕ У РОМАНУ ДЕРВИШ И СМРТ МЕШЕ СЕЛИМОВИЋА
}

У раду се анализирају семантички односи лексема које се синонимно или концептуално, на основу искуственог повезивања представа, обједињују у језичко-стилској слици тематског комплекса самоће, као и синтаксичке форме којима се та слика обликује. Анализа се, као претежно дескриптивна, проводи на лексичко-семантичком, синтаксичком и стилистичком плану. Елементи концептуалне анализе лексичког значења укључују се да би се тематски комплекс самоће приказао у међуодносу искуственог и књижевноумјетничког обликовања његовог смисла у оквиру дјела као цјелине.

Кључне ријечи: самоћа, семантичко поље, синонимија, синегдоха, кумулација, контраст, квантификација

Тематско-мотивски комплекс самоће, као један од централних у роману Дервиш и смрй, на семантичком плану реализује се у оквиру семантичког поља лексеме сам (полазећи од њеног значења „одвојен од других”) и развија се у концепт ${ }^{1}$ који комплексно обједињује

1 У вези са термином концепт употребљавају се из когнитивне лингвистике сљедећи појмови у значењима: домен - сегмент знања који се активира у свијести интерпретатора значења 
„језичку слику света својствену носиоцима српског језика” са „мисаоно-филозофском” у „уметничко-естетску” (Ристић 2015: 325), па се концептуализација значења самоће у оквиру ове теме посматра „и као континуални и као живи процес развијања општег смисла" (Ристић 2017: 152), својственог књижевном тексту. Апстрактне и сложене појмове, какав је и појам самоће, „не доживљавамо непосредно, већ тако што их конкретизујемо и поједностављујемо, сводимо их на познато искуство” (Драгићевић 2007: 90). Концептуализација у лингвистици обухвата виђење, структурисање и кодирање одређене појаве од стране интерпретатора њеног значења - у књижевном тексту она је уобличена на основу језичке и социо-културне компетенције аутора, па се у њој сажимају различити аспекти језичког знања, денотативни и конотативни, и његовог преобликовања у умјетничко-естетску поруку разноврсним стилематичним поступцима. У граматичкој структури, јединице које манифестују значења самоће обликују разноврсне перифразе у форми унутарреченичних и реченично-исказних конструкција, као и на нивоу текста. Предмет анализе јесу те паралеле и мрежа формално-семантичких односа које дати темат-

неког појма, а који учествује у обликовању значења одређене појмовне структуре и представља основу концептуализације (издвајају се базични или изворни домени, који су елементи физичког искуства и не могу се даље разлагати, као што су нпр. простор, вријеме, звук, тежина, боја, мирис, окус и сл. и апстрактни или циљни домени, као што су живот, љубав, туга и сл. који се на основу поступа концептуалне метафоре или метонимије пресликавају у изворне, нпр. живот је путовање);

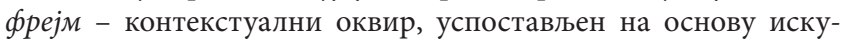
става и знања о свијету, у коме се разумије значење неког појма, а који сачињава скуп домена; схема - пресликавање конкретних (физичких) искустава о свијету на апстрактне појаве; сценариј - скуп поступака (или очекивања) на основу којих се развија посматрани догађај (в. Лангакер1987). 
ски блок одређују на лексичко-семантичком, синтаксичко-семантичком и стилистичком плану.

Самоћа, усамљеност, самотништво у роману су предодређени самим насловом Дервиш и смрй, јер су инкорпорирани и у једној и у другој лексеми које затварају круг (а Селимовићу је мотив круга врло својствен) животног пута главног јунака. Стање смрти је стање коначне, предимензиониране самоће, напуштања, одвајања од овог свијета, нестанка (Smrt je promjena stanja. Duša počinje da živi sama $17^{2}$ ). Нурудин је дервиш, а gервиш је „муслимански свештиеник, калуђер (РМС 2007: 268)” или „муслимански аскета, односно следбеник суфизма, мистичког учења у исламу, од кога се захтева завет сиромаштву и чедности: они су дужни да проповедају, да се моле и да воде честит живот". ${ }^{3}$ По природи ствари дервиш је усамъьник или „онај који се йовукао у самоћу, који йроводи животи на неком усамтеном местиу (уілавном као исйосник)" (РМС: 1410), па је самоћа природни амбијент у коме он и иначе живи. Одвојеност од других упућује на усамљеност у себи која се вишеструко квалификативно-квантификативно усложњава и манифестује се у ширим смислу као усамљеност у свијету - и религије и разних периода свјетовног живота главног јунака. Тако је дескрипција самоће као апстрактног концепта осјећања осликана и физичким реалијама - референцијалношћу конкретног простора (текијског и тамничког) и тишине у којима се главни јунак Ахмед Нурудин креће и које осјећа. Његова лична несрећа, братово страдање које није спријечио или није могао да спријечи - суочавање са животним проблемима чије рјешавање га води у сукоб са апсолутном влашћу, у тоталну изолацију из друштва

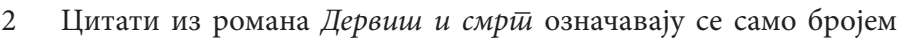
стране, а комплетан библиографски податак о роману дат је у додатку „Извори”, на крају рада.

3 https://sr.wikipedia.org/sr-ес/, приступљено 7. 5. 2019. године. 
(чак и када се власти у немоћи и жељи за осветом приклања) - градацијски продубљују то осјећање и оно се вишеструко умножава и преноси са унутрашњег плана на околни свијет у коме се манифестује у домену тишине и издвојеног, ограниченог и зидовима изолованог простора. Тако дескрипција самоће обухвата и дескрипцију унутрашњег стања лика или JA-наратора и дескрипцију за самоћу типичног амбијента.

Полазна у анализи, по логици граматичке једноставности а и по фреквентности у корпусном тексту, јесте лексема из средишта семантичког поља, односно лексема сам, која у обликовању концепта самоће партиципира својим секундарним значењем. Будући да је та ријеч полисемична, она се у семантичко поље самоће, која је „стиане оввојеностии оg љуяи, осама, усамлености, самойиюа" (РМС 2007: 1190), не центрира својим примарним значењем, него секундарним. Њено примарно рјечничко значење - „1. а. лище које самосйално, без йомоћи и мешань gруіих учестивује у раяни или оg коїа йойиче раяна: он (ја, $\bar{u} u)$ тично" (РМС 2007: 1186) - показује сљедећи примјер:

moli me da govorim sa Hasanom, da se on sam, dobrovoljno odrekne nasljedstva... (29).

Ово значење лексеме сам, иако у архисеми значи „појединачност без учешћа других” не спада у семантичко поље самоће, јер не означава емоционално стање издвојености, него самосталност у неком дјеловању. Лексема сам је у датом значењу наведеном архисемом подударна са значењем лексеме самоћа, али није синонимна са њом, јер се односи на радњу, а не на стање, а самоћа је стање. У датом примјеру, дакле, реализовано је основно значење лексеме сам према рјечничкој дефиницији, што је у примјеру наглашено и прилошким појашњењем 
gобровољно (da se on sam, dobrovoljno odrekne nasljedstva). Обављање својом вољом, добровољно, неке радње озна-

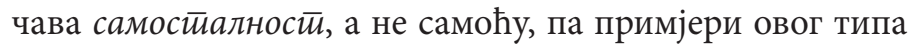
не чине анализирани корпус.

У суштини значења самоће јесте секундарно значење лексеме сам према коме бити сам значи бити „оgвојен og gруїuх, ঠез икоїa gруїо̄, јеgан јеgини, усамљен" (РМС 2007: 1187). У роману се самоћа врло често и експлицира управо лексемом сам, и то најчешће тако што је та ријеч предикатив у дескриптивној реченици.

Сам је предикатив - у оквиру предиката или у елиптираној реченици:

1) Uništila me tuga, i bio sam sam (225); Ne znam šta bi se desilo, možda mi ne bi znao ništa reći, možda mi ne bi mogao ničim pomoći, ali bi popustio grč moje duše, i ne bih bio sam (124); Opet sam sam. Možda je najbolje tako, ne očekuješ pomoć i ne bojiš se izdaje. $\underline{\text { Sam }}(156)$; Ostaću u mraku dugo, bojim se. $\underline{\text { Sam }}$ (225). $\underline{\text { Sam. Sam. Sam. Sam, }}$ kao pod krivicom (429). Molio sam za nju uzalud. I odveo tebe u drugo selo, da ne vidiš. Poslije plakao, skriven, sam, zgađen na ljude, a žaleći ih, jer su cio dan skrivali oči jedan od drugog, zbog stida (292).

Будући да сама конструкција копулативног предиката има дескриптивно значење, квалификативна вриједност лексеме сам тиме је додатно наглашена. Сам је квалификација која се приписује субјекту (bio sam sam)

4 сам, сама, -о I. заменички придев (уз именице и личне заменице) који служи за истицање, а означава: „1. а. тище које самосииално, без иомоћи и мешаға яруіих учестивује у раяюи или оg коїа йойиче раgюа: он (ја, $\bar{u} и)$ тично" [...]. IІ.прид. 1. а. оgвојен og gруїих, без икоїа gруі̄ō̄, јеgан јеgини, усамъен: поћи сам на пут, остати сам у кући, једро, само у даљини. б. који је без йороguце, без рођака, без блискої: бити сам без икога свога, без својих блиских (РМС 2007: 1186 -1187). 
и итеративно понавља (Opet sam sam). То стање је представљено као посљедица деструктивног дјеловања са самоћом узрочно-посљедично повезаних стања субјекта: $\bar{u} y \bar{i} e$ (Uništila me tuga, i bio sam sam) и стираха од самог себе, као осјећаја кривице (Ostaću u mraku dugo, bojim se. Sam; Sam. Sam. Sam. Sam, kao pod krivicom) или од напуштености од блиских људи, односно од страха од uзgaje (Opet sam sam. Možda je najbolje tako, ne očekuješ pomoć i ne bojiš se izdaje. Sam). Тиме се већ у овим иницијалним примјерима успоставља емоционално-мисаони комплекс стања и појава којима се самоћа субјекта поставља у шири оквир његовог интимног свијета и функционисања у микросоцијалном контексту који чини окружење у коме се та стања развијају и од кога посредно или непосредно зависе. Успостављају се релације: самоћа-туга и самоћа-издаја, самоћа-кривица које представљају не само узрочно-посљедичну везу него суштинску емоционалну и мисаоно-смисаону подлогу. Ти проблеми се тематизују у романа као цјелини. Tyīa је „душевни бол, душевна патња” (РМС 2007: 1348) и води у стање осамљености као врсте душевне болести која га уништава (Uništila me tuga). Изgaja је „неверство [...] прелазак на непријатељску страну” (РМС 2007: 454) и манифестује се у доживљајном свијету Ахмета Нурудина као аутоиздаја - изједа га осјећај да је издао брата Харуна, пријатеља Хасана, родитеље, жену коју је волио, дјечака у мочвари (Мула Јусуфа), чију мајку није заштитио од страдања, принципе према којима је живио - и као издаја од стране оних којима се отворио пријатељски или је од њих очекивао помоћ - од стране жене коју је волио (удала се, није га сачекала да се врати са војне), Мула Јусуфа, Хасана (док чека да га ослободе из Тврђаве), оца (јер се помирио са тим да он за њега не постоји и брине се само о судбини другог сина Харуна), од људи генерално којима је као шеик служио, вјером их штитећи 
од зла итд. Аутоиздаја води посљедично у кривицу коју је немогуће превазићи, а која се манифестује као „йраіична кривииа" - „ірешка, ирестиуй, ирекршај (обично моралне ӣрирове) који учини јунак йраїеgије у йежни gа остивари свој ияеални ииль, збоі чеїа на крају мора gа cūpaga" (РМC 2007: 591). Самоћа, коју осјећа и у којој живи, ствара привид успостављања мира у Нурудиновом узбурканом доживљајном свијету.

У истотипском предикату лексема сам у изражавању појачаног значења осамљености повезује се и са глаголом

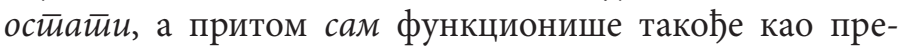
дикатив. Глагол остиайи тада реализује једно од својих значења које је подударно значењу копулативног глагола $\delta u \bar{u} u$, што се наводи и у Матичином једнотомном Реч-

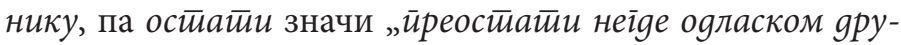

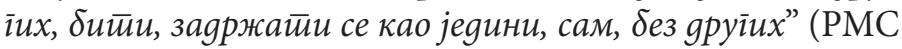
2007: 894):

1a) Ljudi su izlazili kašljucajući, tiho šapućući, ostavljali su me, ostao sam na koljenima pred mukom, sam, srećom, sam, na žalost, bojeći se da napustim ovo mjesto...(108).

Пошто је у предикату фактички придјевска лексема сам садржана у значењу глагола остиай - дјелује и као интензификатор. Према распореду конституената у стилизованој реченици синтаксички статус њене унутарпредикатске (ostao sam na koljenima pred mukom, sam, srećom, sam, na žalost) или пак постпредикатске реитерације, ако се предикат одреди као перифраза глагола клечатии (ostao sam na koljenima pred mukom, sam... = клечао сам на кољенима, сам...), могао би се подвести и под предикативни апозитив са квалификативним и пропратнооколносним значењем, па њена вишефункционалност усмјерава и њену вишезначност. Та квалификативна вишезначност одражава се и квантификативно, 
чему доприноси и антонимијски однос модалних прилога срећом и нажалости (sam, srećom, sam, na žalost), који обухватају и опсег пожељног и непожељног простора манифестације маркираног осјећања усамљености.

У исказивању опсега усамљености често лексема сам (као предикатив или предикативни апозитив) колоцира са локализатором:

16) Sam u polju, sam u svijetu, nemoćan pred tajnama zemlje i širinama neba (111); Ostavši sam, sam na cijelom svijetu, u jakom svjetlu svijeća, u najcrnjoj tami, ne olakšavši ništa u sebi ... udario sam čelom o pod, i znajući, avaj, da je uzaludno, u očajanju izgovorio riječi Bakara sureta... (224)

Локализатором се одређују димензије усамљености - конкретно-референцијално (сам у йољу; у јаком свјетилу свијећа) или експресивно-емоционално (у најuрғьој йами) или пак квантификативно - у простору схваћеном у максималној обухваћености (сам у свијетиу; саму на иијелом свијетиу). Битии сам на иијелом свијетиу има надсуперлативну вриједност квалификације самоће, наравно, перифрастично изражену. Лексема сам подложна је квантификовању, а тиме се и самоћа реализује у различитом степену, што је у роману вишеструко уочљиво. Креће се од религијским каноном предодређене - дервишке усамљености која је мање-више изабрани и неоптерећујући начин живота, одређен затвореношћу, тишином и самоћом (Šta traži u ovoj tišini svetog mjesta, u tvrdim okovima derviškog reda, on je od onog svijeta ... ugušiće ga ova tekijska tišina, i samoća, zašto se ne vrati u noć i ne bude ono što je... 45-46) преко изабране и циљане усамљености као предаха од људи и њихових проблема (Da se opet vratim sebi i tekiji. ... volim je što sam zaštićen mirom mojih dviju soba, u kojima mogu da budem sam kad se odmaram od ljudi 14) - до коначне и неповратне, када 
појединац није више ни сам на цијелом свијету, него овај свијет не постоји и нестаје када га његова душа напушта (Smrt, kraj. I odjednom, kao da sam progledao pred tamom što mi je prijetila, obuzeo me užas od nepostojanja, od tog ničega 476).

Код Селимовића је фреквентна, а такође у функцији квантификовања квалификативног садржаја самоће, и плеонастична конструкција сам са собом - у значењу без присуства других људи у околини и у свијести појединца, чиме се актуализује свјесна или принудна егоцентричност:

1в) Trebalo je da ostanem sa pasavandžijom, da ne budem sam sa sobom i svojom nemoći da se oduprem i pomirim (172); Tako sam najčešće ostajao sam, s knjigom ili sa svojim mislima, ne uspijevajući da uočim ni jednog čovjeka s kojim bih želio da se zbližim (269); Svjestan sam da pišem zapleteno, ruka mi drhti otplitanja što mi predstoji, zbog suđenja koje otpočinjem, a sve sam ja na tom suđenju, i sudija i svjedok i tuženi (9); ... i moći ću na kraju da donesem presudu sam sebi, jer sam samo ja u pitanju, niko drugi, samo ja. Svijet mi je odjednom postao tajna, i ja svijetu, stali smo jedan prema drugome, začuđeno se gledamo, ne raspoznajemo se, ne razumijemo se više (14).

Конструкција сам са собом плеонастичне је структуре јер компонента са собом подразумијева се у значењу сам, па је квазисоцијативни инструментал са собом само интензификатор значења сам, појачава га и затвара у унутрашњи доживљајни свијет ЈА-субјекта. Координираним додатком сам са собом и својом немоћи тематизује се узрок његове самоће (немоћ субјекта да се одупре проблемима и помири са њом). По истом моделу је и конструкција сам с книіом или са својим мислима, али је њена синтаксичка семантика усмјерена на информацију о начину реализовања самоће у реалном понашању. Дис- 
трибуцијом, која се семантичким обједињавањем референта трансформише у кумулацију, ${ }^{5}$ и синдетом у трећем примјеру (a sve sam ja na tom suđenju, i sudija i svjedok i tuženi) наглашена је збирност универзалног квантификатора све, чије компоненте експлицирају опсег егоцентричне усамљености у оквиру ЈА, које је „и судија и свједок и тужени". У посљедњем примјеру усамљеност ЈА контрастира са одричним универзалним квантификатором нико (jer sam samo ja u pitanju, niko drugi, samo ja.), који искључује постојање gруі̄oīa, чије би присуство и саучествовање поништило самоћу. У том примјеру контрастирају се ЈА и „свијет”, или све што постоји, укључујући и људе и човјеково материјално и нематеријално окружење, па је усамљеност универзална у највећим могућим границама егоцентризације Нурудиновог доживљајног свијета.

Синониман придјевској ријечи сам јесте придјев једини:

1) Vraćao sam se prema tekiji, pogružen, utučen, možda jedini nesrećan čovjek te večeri u kasabi” (40); Nikoga nema na polju prepolovljenom sjenkom, puste su obje strane, jedini ja stojim na toj zavađenoj širini što se zamračuje, sitan u prostoru što se zatvara, obuzet mutnim tjeskobama koje nosi moja prastara duša, tuđa a moja (111):

Ситуирање у контекст, у неки простор или у друштвену групу, неопходно је и уз придјев јеguни, будући да подразумијева и компоненту изузимаға og gруїux у означеном контексту (jedini nesrećan čovjek

5 Дистирибуиија је нагомилавање јединица уз апстрактни катафорски појам, као што је све, при чему су те јединице разнореференцијалне (нпр.: „Све је пјевало у кору, и цврчци, и шкаре, и овце..."), док је кумулација нагомилавање синонимних, односно истореференцијалних јединица које пилонски референт представљају различитим семантичким компонентама (према: Ковачевић 2015: 126-131). 
te večeri u kasabi; jedini ja stojim na toj zavađenoj širini ). Слична је и семантичка вриједност партикула јеgино и само и приједлога осим као конкретизатора у ексклузивним и ексцептивним конструкцијама, које представља и претходни примјер Никоїа нема на йољу ... јеgини ја сииојим у йој завађеној ширини, а и сљедећи:

2) Ničega nema, samo moja uzbuđena vrelina živi u ovoj pustolini (238); Ali ja nemam drugog puta i nikome ne mogu da kažem osim sebi i hartiji (11).

Да би се искључивање или изузимање реализовало као усамљена појединачност, у међуодносу су универзални квантификатор - одрични када је оно што се изузима у потврдној реченици (а афирмативни - уколико је конструкција са рестриктивном ријечцом одрична). Тако су у датом примјеру у међуодносу нишй $a$, тј. ничеї нема - чиме се одриче постојање других - и доживљајни свијет ЈА-субјекта, уведен рестриктивним интензифика-

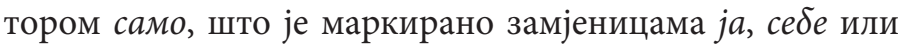
њима еквивалентним морфолошким категоријама - у датом примјеру присвојном замјеницом моја (samo moja uzbuđena vrelina živi u ovoj pustolini). Значење издвојености као самоће појачано је и значењем локализатора у овој $\bar{u} y с \bar{и} о л и н и, ~ ј е р ~ и ̆ у с и ̆ о л и н а, ~ к а о ~ и ~ п р и д ј е в ~ и ̆ у с \overline{u ~ о з н а ч а в а ~}$ простор „у коме или на коме нема ничега, у коме или на коме не живе људи" (РМС 2007: 1094), па конструкција синегдохом представљеног субјекта самоће (samo mоја uzbuđena vrelina) који се лоцира „у пустолини” као празном простору апсурдно наглашава суштинске семантичке компоненте усамљености. Апсурд је изражен и на лексичкосемантичком плану, јер „у пустолини”, као простору „у коме или на коме нема ничега, у коме или на коме не живе људи" - живи усамљеност. У датим примјерима усамљеност ЈА-субјекта наглашена је и контрастом 
који ексцептивне конструкције у којима се дио изузима из цјелине увијек садрже.

Значење самоће изражава се придјевом усамљен и именицом усамъеносй:

3) Glas je zagrobni, beznadežno tužan, potpuno usamljen i gore je što ga čujem, jer govori i o mojoj usamljenosti; Porazila me misao koja mi se tada otkrila, koliko sam odvojen od ljudi, koliko sam usamljen (304); Bio sam usamljen, napušten od svih ljudi, ostavljen u praznoj tišini svoje nesreće (298); U meni nemoćna ravnodušnost i tišina bez života. Vidjela u meni nema, kao u nevjernicima (172).

У првом примјеру из ове групе синегдохом ілас обиљежава се усамљеност непознатог човјека, робијаша, а он је усамљен йоййуно. У смисаону цјелину повезују се туга (beznadežno tužan) и беживотност (Glas je zagrobni; U meni nemoćna ravnodušnost i tišina bez života), што упућује на већ објашњени узрочно-посљедични однос тих стања. Усамљеност је у затвору квантификована и изражена у највећем степену - као „потпуна” и показује мјеру изолованости појединца и физичком и у емоционалном смислу (Porazila me misao koja mi se tada otkrila, koliko sam odvojen od ljudi, koliko sam usamljen). Квантификативно-квалификативни степен самоће, самјерљив са емоционалним значењем лексеме $\bar{u} y \bar{i} a$ прераста у виши степен негативно маркираних осјећања која се подводе под значење лексеме несрећа, па је онај ко је несрећан „невољник, јадник” (РМС 2007: 829), а

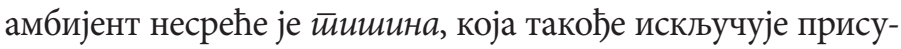
ство других и појачава степен усамљености појединца (Bio sam usamljen, napušten od svih ljudi, ostavljen u praznoj tišini svoje nesreće) и тама (Vidjela u meni nema).

У наредним примјерима Селимовић поступком парафразе и метајезичке преформулације у координираним конструкцијама (пре)формулише значење придјева 
усамљен на два начина која одражавају доживљај самоће од стране ЈА-субјекта. Усамљен је онај ко је одвојен, а та одвојеност је лична, узрокована његовим доживљајем и ставом према људима, он је, дакле, њен субјекат (колико сам оgвојен оg љуgи, колико сам усамлен;) али усамљен је и онај који је напуштен од људи, који је објекат усамљености као остављености од других (био сам усамъен, найушиеен оg свих љуяи). Самоћа као издвојеност у односу на друге реализује се глаголима изgвојити $u$,

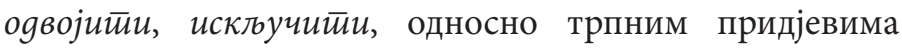
изявојен, оввојен, искључен, осамостиаљен и сви су они

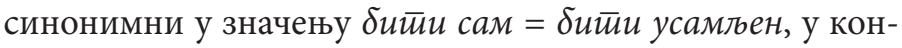
струкцијама типа Издвојен сам:

4) ...izgledalo je da u ovoj đurđevdanskoj noći kasaba cepti u groznici. I odjednom, bez ikakva razloga, osjetih da sam izdvojen iz svega ovoga (38). Zapamtio sam tu noć ... Bog je htio da ona bude drukčija od ostalih, da se u njoj sluči, kao na dugo pripremanom sretanju, sve što je rascijepilo moj život na dvije polovine, i da me odvoji od svega što sam bio četrdeset mirnih godina (40); Htio sam da ostanem sam sa sobom (47); Isključio sam se, i bio isključen, odvojen od svega oko sebe, i svijet je prilično avetinjski, živ ali ravnodušan. A i ja sam osamostaljen i neprobojan (48); Ušao sam u tekiju, okrenuvši ključ u zarđaloj bravi. $\underline{U}$ sobi sam joščuo škripavi zvuk kojim sam se odvojio" (56).

Истог значења синонимних блискозначница са сам

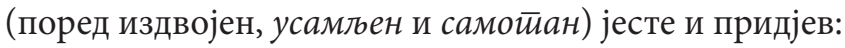

5) Otišao sam u svoju sobu ... Odbijala me svojom pustoši, zaboravili smo se dok sam tragao za tajnom, a ništa nisam našao na drugom mjestu (306); Čudan svijet, mislio sam idući pustim sokacima (171); Žao mi je što je potpuno izgubio vjeru u ljude. Biće nesrećan i pust u sebi (75). 
Значење усамљености изражава и придјев ирразан:

6) Osjećao sam se prazan i usamljen (434); A onda je došla prazna tišina (245); ...Sam sam u tišini prazne džamije (222).

Самоћа је одређена и као самотност простора - тиекије и текијске башче опасане зидинама и тишином (Tekija je lijepa i prostrana ... sa dugom divanhanom u kojoj je tišina mekana kao pamuk, još tiša zbog sitnog žubora rječice ispod nje - 12), које одвајају текију од остатка свијета:

7) Gusti mušebeci i debeli zid oko bašče činili su našu samotnost tvrđom i sigurnijom... (13); Da se opet vratim sebi i tekiji. ... volim je što sam zaštićen mirom mojih dviju soba, u kojima mogu da budem sam kad se odmaram od ljudi (14); Tekija je izgledala kao utočište, čiji će me debeli zidovi vratiti tišini koja mi je potrebna i miru koji neće biti gađenje (40).

У том контексту самоћа је природно стање живота дервишког реда и није деструктивна, него простор сигурности и мира, квалификација и простора и тишине није непријатна, него је уобичајена, самјерљива са животом у вјери и посвећености молитви:

8) A kad sam naslućivao makar i nagovještaj uzburkanosti, stješnjavao sam se u četiri zida svoje sobe, i prisiljavao se da idem poznatom tvrdom stazom molitve (41).

У том смислу, самоћа је за Нурудина уточиште и бијег од животних изазова у нихилистички страх од свијета и живота који га мами својим изазовима:

9) Te noći nisam mogao da ostanem u bašči, potrebno mi je bilo da se odvojim, da zaboravim, a ovdje se sve nametalo kao izazov. Mjesečina je ledena i kao da je zaudarala na 
sumpor, cvijeće je mirisalo prejako, razdražujuće, počupati bi ga trebalo, pogaziti nogama, da ostane samo čkalj i pusta ledina, da ostane mezarje, bez oznaka, da ne podsjeća ninašto, da ostane gola ljudska misao, bez slike, bez mirisa, bez veze sa stvarima oko nas, i rijeku bi trebalo zaustaviti da ne žubori, i ptice podaviti po krošnjama i pod strehama da ne ćućore besmisleno, i porušiti sve vodenice pod kojima se kupaju gole djevojke, zagraditi sokake, zakovati kapije, silom uništiti život, da ne buja zlo. Urazumi me, Bože. Nikad nisam sa takvim nerazumnim bijesom mislio o ljudima i životu. Uplašio sam se. Odakle ta želja da ničega ne bude? (41-42).

У роману овакви примјери функционишу као носталгични контекст са којим се упоређује ишчитавање супротног значења истог простора и амбијента у коме се субјекат, под притиском негативних емоција, више не осјећа ни сигурно ни заштићено, који доживљава као амбијент у коме се његова усамљеност, као и у затвореном простору затвора, тврђаве, круга, гроба - материјализује.

„Стјешњавање међу четири зида” јесте самовање. А самоћа се конкретизује не само у простору него и у аудитивном смислу - идентификује се тишином као одсуством других који могу да је наруше и води коначној и самоћи и тишини које симболишу смрт:

10) Nikog ne vidim, nikog ne poznam, znam samo da su zatvorili krug oko nas i ostavili me samog u mučnoj tišini nad mrtvacem (18).

Самоћа је за њега усуд који га је одвојио и од породице, у њој се мимоишао с братом и склизнуо у кривицу, па га пронашао у његовој сопственој самоћи и страдању:

11) Sad smo jednaki, nesrećni obojica; ako sam kriv, sad krivice nema, znam kako si bio sam, i kako si čekao da ti se 
neko javi, stajao si na vratima, osluškivao glasove ... Ostali smo usamljeni i ja i ti, niko nije došao, niko nije upitao za mene, niko se nije sjetio, prazna je ostala moja staza, bez traga i bez uspomene, volio bih da to nisam vidio. Ti si čekao mene, ja sam čekao Hasana, nismo dočekali, nikad niko ne dočeka, svako uvijek na kraju ostane sam (246).

Осликана је тамним бојама и обиљежава крај живота и одашиље поруку да је у тренутку смрти свако коначно и потпуно сам:

12) Ustao sam i prišao otvorenom prozoru. Tišina, tama. Potpuna, konačna. Nigdje ničega, nigdje nikoga. Prestala je da kuca i posljednja žila, utulilo se i posljednje vidjelo. Ni glasa, ni daha, ni truni svjetla. $O$, svijete, pustoši, zašto baš sada tako? (494).

Самоћа Ахмеда Нурудина исписује и затвара круг који се спаја у тачки сусрета живота и смрти. А из тишине и таме, без игдје ичега и нигдје никога, без видјела, гласа, даха, ни труни сјетла - у том опскурном опису кроз отворени прозор самртне самоће ипак зјапи на крају Нурудиновог самотничког пута закашњело питање „О, svijete, pustoši, zašto baš sada tako?” и отвара исконску побуну којом се живот супротставља смрти, а нихилистичкој концепцији свијета просјај виталистичке.

Концептуализација самоће у роману Дервиш и смрй обједињује појмове који представљају апстракције и реалије човјековог физичког, чулног, емоционалног и интелектуалног искуства о свијету. Темељи се на осликавању и структурисању те апстрактне појаве од стране интерпретатора њеног значења у симболици конкретних значења простора, звука, боје, као и квантитативних параметара појединачности наспрам разних типова социокултурних кругова - као што су дервишки ред и 
његова догма, породица и њене везе присности, пријатељи, друштвене институције и друштво уопште. Тако је самоћа одређена доменом одсуства - као појединачности или издвојености од других - од жене, породице и пријатеља, одсуством других у простору или празним простором, ограниченим димензијама собе, џамије, текијског зида, затвора, а који се апстрахује затвореношћу животног круга; доменом одсуства звука - тишином и тамним бојама „без свјетла, „без видјела”, као симболичног колорита човјекове неиспуњености и празнине. На емоционалном плану самоћа је у узрочно-посљедичном односу са тугом и душевним болом као својеврсном деструкцијом бића, својственом болести, која га чини несрећним у амбигвитетним друштвеним улогама послушника и побуњеника, судије и окривљеног, у односима кривице и (не)могућности њеног превазилажења, дубоке и изгубљене љубави, искреног и непостојаног пријатељства, побуне против власти и уживања у снази коју му она даје - у моћи и немоћи. Између тих полова који самоћу продубљују и развијају успоставља се круг из кога усамљеник не може изаћи, а који је детерминисан почетком и крајем живота, чињеницом да је сваки човјек сам и у тренутку рађања и у тренутку умирања, да је сам у животу и да из самоће не може пронаћи излаз, јер не може пронаћи смисао живота, ако, према једном од Селимовићевих коментара Нурудиновог лика, ${ }^{6}$ изабравши пут мржње и освете - одбаци љубав.

6 В. интевју М. Селимовића „Boja Derviša”, NIN, 1969, razgovor vodila Marina Tumić-Kisić, u: M. Selimović, Pisci, mišljenja i razgovori (eseji, članci, polemike, intervjui), Beograd - Sarajevo: BIGZ Svjetlost, 1990, 335. 


\section{Извори}

Meša Selimović (1990), Derviš i smrt, Beograd - Sarajevo: BIGZ Svjetlost.

\section{Литература}

Драгићевић 2007: Р. Драгићевић, Лексиколоїија срӣскоі̄ језика, Београд: Завод за уџбенике.

Багић 2012: K. Bagić, Rječnik stilskih figura, Zagreb: Školska knjiga.

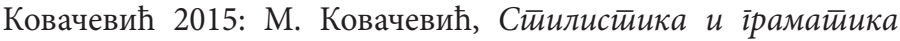
стиилских фиіура, Београд: Јасен.

Лангакер 1987: R. W. Langacker, Foundations of Cognitive

Grammar, Theoretical Prerequisites, Vol. 1, Stanford, California:

Stanford University Press.

Лешић 2005: Z. Lešić, Teorija književnosti, Sarajevo: Sarajevo Publishing.

Лич 1983: Е. Лич, Кулиичра и комуникаиија, Београд: Просвета. РМС 2007: Речник срӣскоїа језика, Нови Сад: Матица српска.

Расулић-Кликовац 2014: К. Расулић, Д. Кликовац (уредници), Језик и сазнане, хрестиоматиија из коінитиивне линівистиике, Београд: Филолошки факултет Универзитета у Београду.

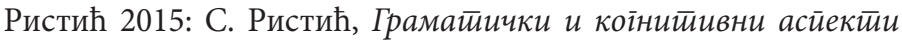
лексичкоі значена, Београд: Институт за српски језик CAHY. 
Milanka Babić

\section{GRAMMAR AND SEMANTICS OF SOLITUDE IN THE NOVEL RAMMAR AND SEMANTICS OF DEATH AND THE DERVISH BY MESA SELIMOVIC}

Solitude, as one of the central thematic and motivational complexitiesin the novel Death and the Dervish, is maintained on the semantic level within the lexeme alone (starting from its genuine meaning "separate from others") and develops into a concept that integrates the linguistic image of the world inherent in speakers of Serbian language from philosophical to artistic-aesthetic level. Thus, the conceptualization of the meaning of solitude within this topic is seen as a living process of developing a general sense that is typical for a literary text. Abstract and complex concepts, such as loneliness, are represented in the novel descriptively, which in a meaningful level is seen in their positioning in a familiar experience that include the motifs of dervish order, as a solitary by its definition, tekija or enclosed, isolated space, then silenceetc. In the grammatical structure, units that manifest the meanings of solitude form various periphrases in terms of inter-sentence and sentence-statement constructions, as well as at the text level. The analyses show these parallels and a network of formal-semantic relations that determine the thematic block on the lexical-semantic, syntactic-semantic and stylistic level.

Key words: solitude, semantic field, synonymy, singdoha, cumulation, contrast, quantification 